\title{
Inverse trends of Campylobacter and Salmonella in Swiss surveillance data, 1988-2013
}

C Schmutz ${ }^{12}$, D Mäusezahl ${ }^{12}$, M Jost ${ }^{3}$, A Baumgartner ${ }^{4}, M_{\text {Mäusezahl-Feuz }}{ }^{3}$

1. Swiss Tropical and Public Health Institute, Basel, Switzerland

2. University of Basel, Basel, Switzerland

3. Swiss Federal Office of Public Health, Bern, Switzerland

4. Swiss Federal Food Safety and Veterinary Office, Bern, Switzerland

Correspondence: Daniel Mäusezahl (daniel.maeusezahl@unibas.ch)

Citation style for this article:

Schmutz C, Mäusezahl D, Jost M, Baumgartner A, Mäusezahl-Feuz M. Inverse trends of Campylobacter and Salmonella in Swiss surveillance data, 1988-2013. Euro Surveill. 2016;21(6):pii=30130. DOI: http://dx.doi.org/10.2807/1560-7917.ES.2016.21.6.30130

Article submitted on 20 March 2015 / accepted on 20 August 2015 / published on 11 February 2016

Clinical isolates of Campylobacter spp. and Salmonella spp. are notifiable in Switzerland. In 1995, Campylobacter replaced Salmonella as the most frequently reported food-borne pathogen. We analysed notification data (1988-2013) for these two bacterial, gastrointestinal pathogens of public health importance in Switzerland. Notification rates were calculated using data for the average resident population. Between 1988 and 2013, notified campylobacteriosis cases doubled from 3,127 to 7,499 , while Salmonella case notifications decreased, from 4,291 to 1,267. Case notifications for both pathogens peaked during summer months. Campylobacter infections showed a distinct winter peak, particularly in the 2011/12, 2012/13 and 2013/14 winter seasons. Campylobacter case notifications showed more frequent infection in males than females in all but 20-24 year-olds. Among reported cases, patients' average age increased for campylobacteriosis but not for salmonellosis. The inverse trends observed in case notifications for the two pathogens indicate an increase in campylobacteriosis cases. It appears unlikely that changes in patients' health-seeking or physicians' testing behaviour would affect Campylobacter and Salmonella case notifications differently. The implementation of legal microbiological criteria for foodstuff was likely an effective means of controlling human salmonellosis. Such criteria should be decreed for Campylobacter, creating incentives for producers to lower Campylobacter prevalence in poultry.

\section{Introduction}

Campylobacter spp. and Salmonella spp. are the most frequently reported zoonotic infections in Switzerland. The Federal Office of Public Health (FOPH) monitors communicable diseases in Switzerland. The National Notification System for Infectious Diseases (NNSID) is an integral part of ensuring compliance with this obligation and was implemented nationwide, in a standardised way, in 1987 . The regulation on communicable disease notifications determines which diseases have to be reported, by whom and in what timeframe [1]. Among food-borne pathogens, Campylobacter spp., Salmonella spp., Listeria spp., enterohaemorrhagic Escherichia coli, Shigella spp., and hepatitis A virus are notifiable. Laboratories must report isolates of Campylobacter and Salmonella within one week of discovery. For patients with suspected bacterial diarrhoea, basic stool culture including Campylobacter spp., Salmonella spp. and Shigella spp. is the routine method of laboratory diagnosis [2].

In humans, campylobacteriosis is most frequently caused by Campylobacter jejuni and C. coli [3]. Signs and symptoms include watery or bloody diarrhoea, fever, abdominal cramps, vomiting and malaise and usually occur after an incubation period of 2-5 days [4]. The disease usually resolves without antibiotic treatment within one week. A recent study on determinants of the disease in Switzerland showed that laboratory-confirmed campylobacteriosis can lead to severe illness in patients [5]. Complications such as Guillain-Barré syndrome can follow Campylobacter infections, although this is rare $[4,6]$. Fatal cases are possible, but the reported case fatality rate of $0.1 \%$ is small and four times lower than the fatality rate for salmonellosis [7].

There are more than 2,600 serovars of Salmonella, of which $S$. enterica subspecies enterica serovars Enteritidis (S. Enteritidis) and Typhimurium ( $S$. Typhimurium) are the most frequently reported [8]. Signs and symptoms of salmonellosis are similar to those of campylobacteriosis but the incubation period is shorter at 6-72 hours (usually $12-36$ hours) [9]. In a group of volunteers, the minimal infectious dose was found to be at least 200 times higher for Salmonella than for Campylobacter (10 $0^{5}-10^{9}$ vs 500 organisms) [10]. However, Salmonella outbreaks have been reported 


\section{FIGURE 1}

Number of Campylobacter and Salmonella case notifications and notification rates registered at the Federal Office of Public Health, Switzerland, 1988-2013

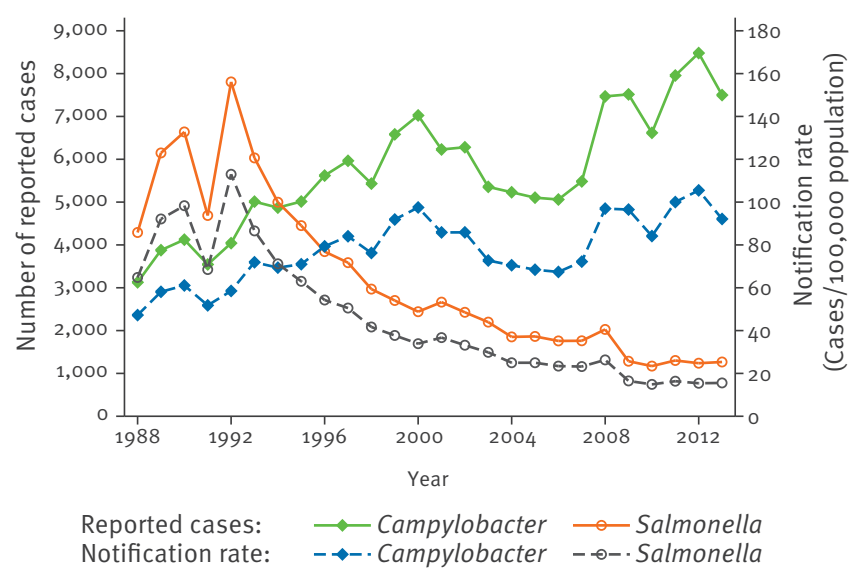

where fewer than 100 organisms had caused disease [11].

In Switzerland, Campylobacter replaced Salmonella as the most frequent food-borne pathogen isolated from clinical specimens in 1995 [12]. In Europe, predominance of Campylobacter has been reported from 2005 onwards [13]. Campylobacter notifications were stable in European Union (EU) countries between 2009 and 2013 while Salmonella notifications declined. Nonetheless, reported food-borne outbreaks were more often caused by Salmonella spp. than by Campylobacter spp. (1,168 vs 414 in 2013).

The aim of this study is to describe the epidemiological patterns and trends of Campylobacter and Salmonella case notifications in Switzerland and to identify factors leading to the inverse trends observed from the NNSID.

\section{Methods}

Medical diagnostic laboratories in Switzerland are obliged by law to report positive Campylobacter and Salmonella test results to the FOPH and to the cantonal chief medical officer in the patient's canton of residence within one week of discovery [1]. Reports must include information on laboratory diagnosis (test result, interpretation, type of sample, detection method and date), patient data (sex, date of birth and place of residence) and physician- and diagnosing laboratory-related data (name, phone and fax number, and address). The FOPH enters the information into the NNSID database. If the patient's canton of residence is unknown, the canton of the reporting laboratory is entered.

The present study used Campylobacter and enteric Salmonella case notification data from the present NNSID's first full year of data collection (1988) until the end of 2013. Data on patients residing outside of Switzerland were excluded. If residency was not specified, the record was kept in the analysis. Notification rates, defined as the number of cases per 100,000 resident population, were calculated. The term 'notification rate' was used instead of 'incidence rate' to be consistent with other authors [13] and because the numbers calculated should not be equated with a true population incidence. To calculate notification rates, data on the average permanent resident population, obtained from the Federal Statistical Office's STATTAB database, were used [14]. Data was analysed and graphically represented using the statistical software Stata (Version 13.0).

\section{Results}

\section{Campylobacteriosis trends}

A 2.5-fold increase in the number of reported campylobacteriosis cases, from 3,127 cases in 1988 to 7,499 cases in 2013, was observed (Figure 1).

Case numbers increased steadily from 1988 to 2000 , until they reached 7,000. Thereafter, Campylobacter case notifications dropped and levelled off at 5,000 cases annually and then rose steadily again from 2007 , exceeding the peak level reached in 2000 . The highest number of cases reported to date was 8,480 cases in 2012. In each year since 1988 , a peak was observed during the summer months (June-August) (Figures 2 and 3).

A second, much shorter peak was noted in December and January in all years. This winter peak has been especially pronounced in the past few years. While the highest weekly case numbers during the summer and winter peaks were comparable in 2009 and 2010, weekly case numbers were much higher during the winter peaks of 2011/12, 2012/13 and 2013/14 compared with the preceding summer peaks (Figure 3 ).

The increase in Campylobacter case notification rates differed by age (Figure 4). Among younger age groups, the increase in notification rates over the years was less pronounced than among older age groups. In children younger than five years old, the notification rates decreased from 105.3 to 102.3 cases per 100,000 population between 1988 and 2013 (-3\%) (Table 1).

This decrease was statistically significant (permutation test for trend, $p=0.03$ ). There was no statistically significant (decreasing or increasing) trend in the 5-9 year-olds; in all older age groups, the increasing trend was statistically significant (permutation test for trend, $p=0.01$ for 20-24 year-olds, $p<0.01$ for all other age groups). Among those aged 85 years and older, the notification rate increased more than seven-fold, from 11.7 to 92.2 cases per 100,000 population during the same time period. The median age of campylobacteriosis patients increased from 25 years (interquartile range, IQR: $17-38$ ) in 1988 to 39 years (IQR: 23-59) in 2013. In all but the $20-24$ year-old age group, notification rates were higher for males than for females (Figure 4). Males accounted for $53.4-57.5 \%$ of total case notifications each year. 
Monthly number of notified campylobacteriosis and salmonellosis cases, Switzerland, 1988-2013

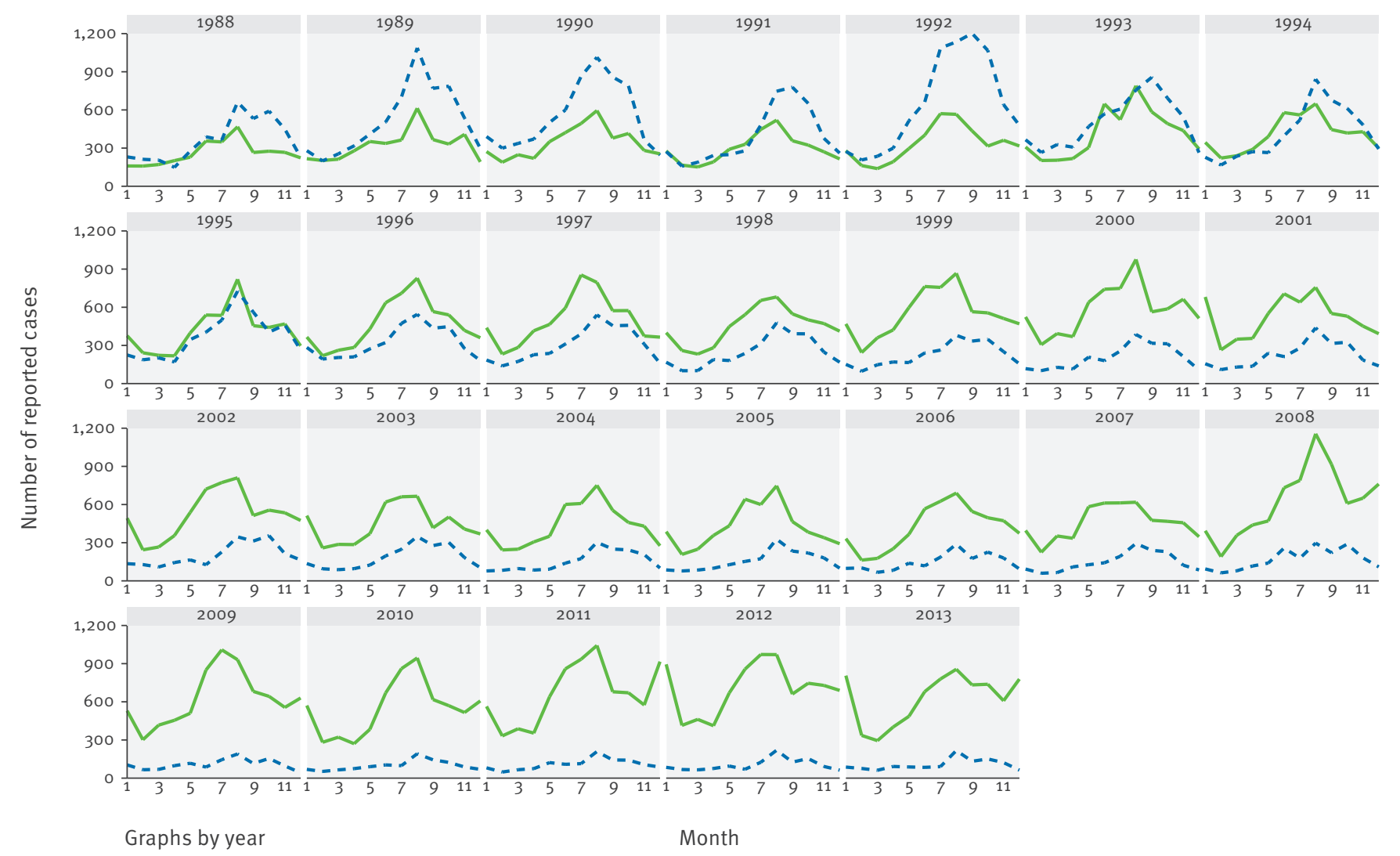

_ Campylobacter - - - - Salmonella

Campylobacter diagnostics identified $C$. jejuni or $C$. coli in the majority of clinical samples (88.5-96.8\% every year; data not shown). For most of the remaining cases, the species was not identified or not reported. Reported sample material came from stool (98.8\%), blood or serum (0.4\%), and other or unspecified materials $(0.8 \%)$. The majority of cases were tested using culture-based methods directly or confirmatively after PCR (> $97 \%)$.

\section{Salmonellosis trends}

Salmonellosis cases reported to the FOPH increased from 4,291 cases in 1988 to 7,806 cases in 1992 (Figure 1). Since 1992, Salmonella case notifications steadily decreased until reaching 1,267 cases in 2013. The highest number of Salmonella case notifications each year was registered in late summer (July-October), indicating a seasonal pattern (Figures 2 and 3 ).

Time trends did not differ between sex and age groups (Table 1, Figure 5).

Each year, $49.6-56.2 \%$ of reported cases occurred in males. The median age of salmonellosis patients increased from 25 years (IQR: 7-44) in 1988 to 29 years (IQR: 11-56) in 2013. In terms of notification rates, the highest absolute reduction occurred in the youngest age group (under five years, Figure 5). The reduction was, however, similar for all age groups when looking at percentage decrease (Table 1). The decreasing trend for all age groups from 1988 to 2013 was statistically significant (permutation test for trend, $p<0.01$ for all age groups).

The two most frequently reported serovars were $S$. Enteritidis (54.0\%) and S. Typhimurium (13.7\%). Other reported $S$. enterica serovars included Virchow, Infantis and the monophasic Typhimurium 4,12:i:- (only differentiated in the notification system since 2010).

\section{Discussion}

In Switzerland, there has been a marked increase in Campylobacter case notifications since 1988, when surveillance began, while case numbers have decreased for salmonellosis. The number of Campylobacter infections nowadays is similar to levels of Salmonella 20 years ago. Salmonellosis has reduced considerably since then, due to control programmes targeting poultry production. Campylobacteriosis has also increased throughout the EU, though the numbers seem to have stabilised between 2009 and 2013; for salmonellosis, a decreasing trend continues [13]. Time trends for Campylobacter in Switzerland differ between age groups, even when looking at age-group-specific 


\section{FIGURE 3}

Weekly number of notified campylobacteriosis and salmonellosis cases, Switzerland, 2009-2013

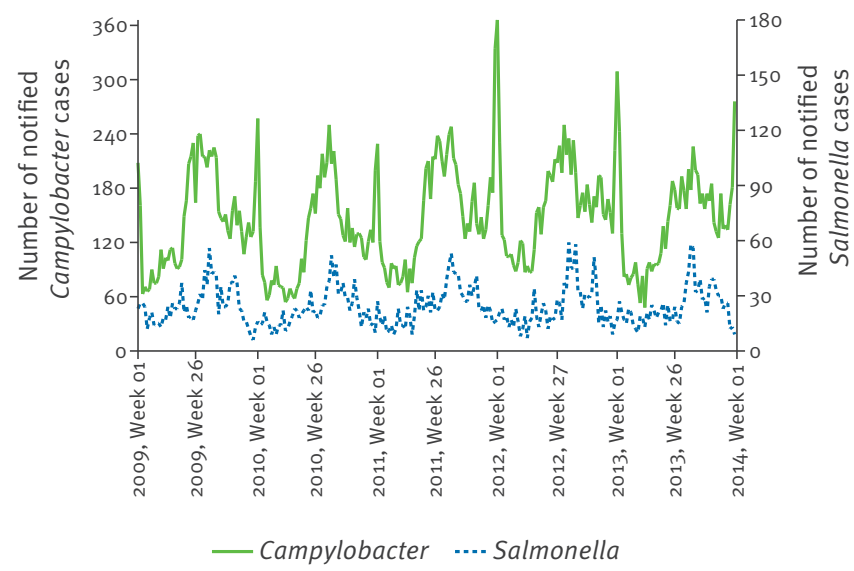

notification rates and adjusting for demographic changes in the population.

True increase in campylobacteriosis frequency One study from the Netherlands showed that stooltesting frequency increased between 1998 and 2008, which might help to explain the increase in campylobacteriosis cases [15]. Along these lines, the decrease in salmonellosis cases would be even larger in the absence of intensified testing.

It is difficult to interpret the changes in the number of positive test results without knowing more about changes in the number of individuals seeking medical consultations, in the proportion of patients being prescribed stool testing and in the total number of tests performed (positive and negative) in Switzerland. Different factors can influence notification data such as changes in risk factors, in patients' health-seeking behaviour, in physician testing practices, in human susceptibility, or in the virulence or pathogenicity of Campylobacter spp. and Salmonella spp.

When a patient presents with acute gastroenteritis necessitating further laboratory testing, Swiss physicians most commonly request basic stool bacteriology, which includes testing for Campylobacter, Salmonella and Shigella (data not shown). Therefore, a change in testing frequency without a change in disease epidemiology would most likely lead to a similar change in both Campylobacter and Salmonella case notifications. Some improvements in stool culture methodology have been made in the past 25 years; however, changes cannot explain the inverse trends observed (personal communication, Roger Stephan, 30 July 2015). Furthermore, negative test results are not notifiable and, hence, the total number of tests (denominator) is unknown. Knowing the denominator would help to confirm or reject the hypothesis that a change in testing frequency does not explain the increase in Campylobacter case notifications and would allow for a better interpretation of the trends observed in the NNSID. Though stool culture methods did not change significantly, the physicians' awareness towards campylobacteriosis is likely to have increased. It is not known to what extent this might have influenced notification data. Changes in patients' health-seeking behaviour are unlikely to influence Campylobacter and Salmonella case notifications in different ways. Consequently, we assume that the decrease in Salmonella case notifications and the increase in Campylobacter case notifications represent real epidemiological trends.

The revised Swiss Epidemics Act effective since January 2016, and its allocated ordinances obligates diagnostic laboratories to report annually the total number of positive and negative Campylobacter and Salmonella tests performed [16]. This innovation will allow basic routine analysis of trends in testing frequency and positivity rates in the future.

\section{The influence of sex and age on food-borne disease notifications}

Salmonella case notifications do not differ between sexes, even when stratified by age groups. In contrast, Campylobacter case notifications reveal higher notification rates among males in all age groups, except for those in the 20-24 year-old group. Interestingly, studies from Germany and England and Wales also show that females in their twenties are more frequently affected by campylobacteriosis than males, while male cases dominate in all other age groups $[17,18]$. Schielke et al. [17] suggested that women in this age group are more frequently involved in childcare activities, which might lead to increased human-to-human transmission. They also suggest that women in this age group are more often exposed to potentially contaminated chicken because they prepare and eat chicken more frequently than men of the same age. They may also be in closer contact with pets, which often harbour the same strains as their owners [19]. Different help-seeking behaviour of patients in this age group or different testing practices of physicians could also explain variations. Moreover, it seems likely that genetic or hormonal factors lead to differences by sex, as notification rates in males and females differ already in the youngest age group (under five years) (Figure 4) [20]. We assume that in the youngest age group, health-seeking behaviour and eating habits are not yet dependent on sex and are rather driven by parents or other persons engaged in childcare.

Available information from England and Wales also shows that adults, including the elderly, increasingly test positive for Campylobacter [18]. It has been suggested that the increasing use of proton pump inhibitors (PPIs) might explain a part of this phenomenon, especially among the elderly. Several studies have found that the use of PPIs is a risk factor for infection with Campylobacter and other enteric pathogens [21]. However, one study revealed that patients prescribed PPIs were already at increased risk of gastrointestinal 
Trends in Campylobacter notification rates between age groups and sexes, Switzerland, 1988-2013

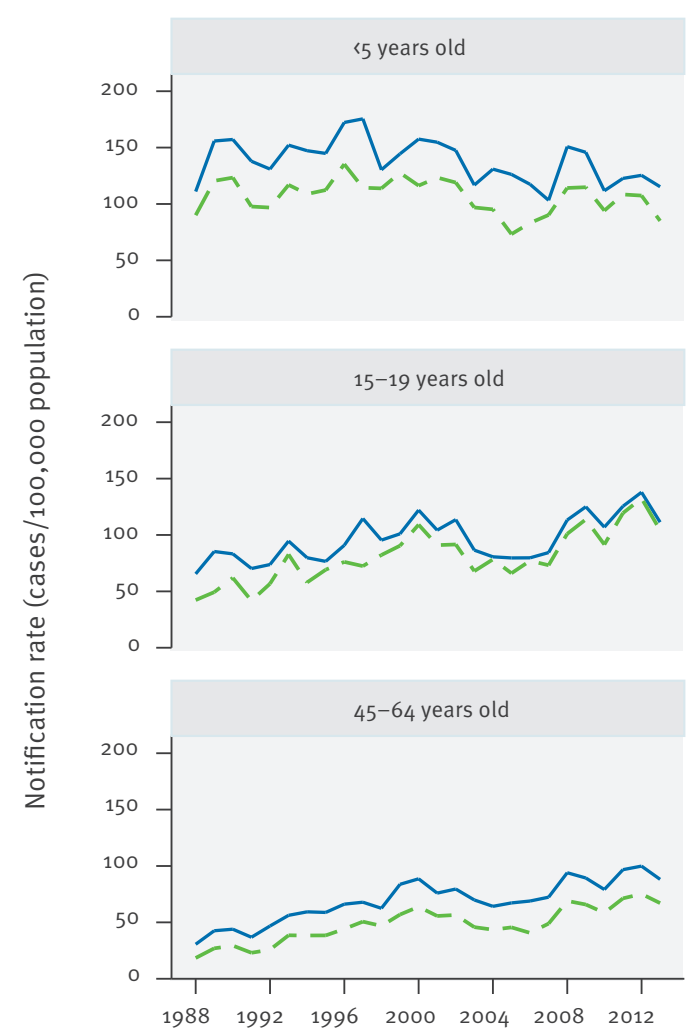

Graphs by age group
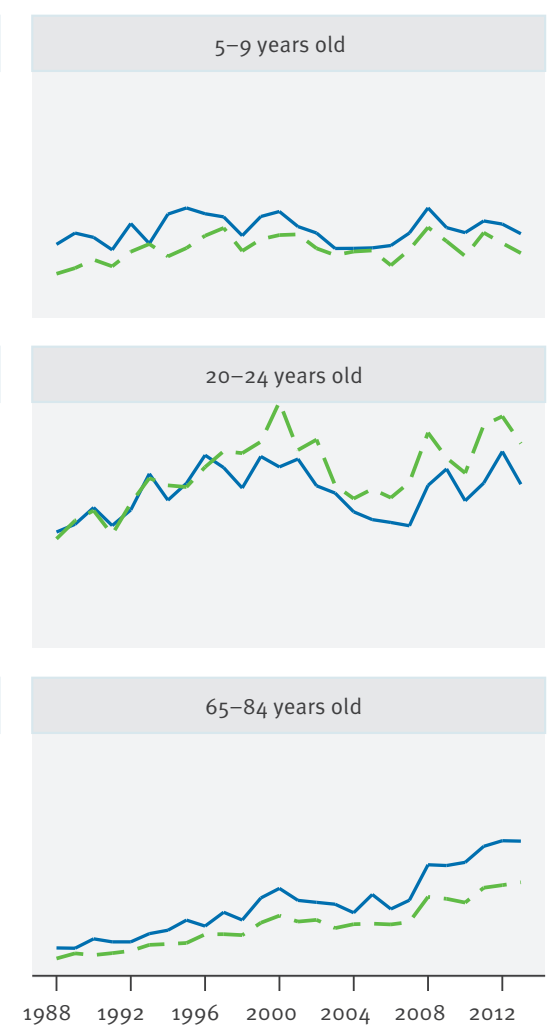
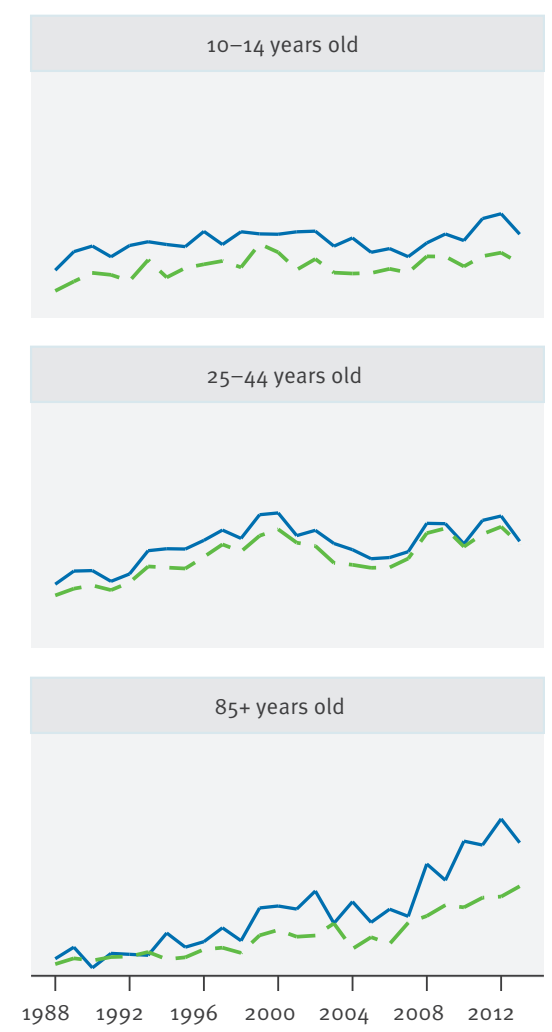

Year

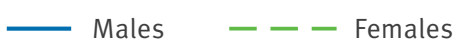

infection, even before prescription of these drugs [22]. In any case, conditions leading to PPI use or prescription are likely associated with acute infectious gastroenteritis. Why the aforementioned risk factor would only influence the frequency of Campylobacter but not Salmonella case notifications remains unknown. One possible explanation is that the infective dose of Campylobacter is generally lower than that of enteric Salmonellae. A recent study of poultry consumers' behaviour, risk perception and knowledge related to campylobacteriosis and domestic food safety showed that unsafe cooks were more likely to be male and of younger age [23]. Even though this finding is consistent with high Campylobacter notification rates observed among young adults, it does not explain the increasing rates among the elderly.

\section{Food safety regulations}

Campylobacter and Salmonella infections are assumed to be mainly food-borne. Genotyping and epidemiological studies in Switzerland have shown that chicken meat is the most likely source of infection in the majority of human campylobacteriosis cases [5,24-26]. In concert with these findings, a recent time-series analysis showed a significant association between Campylobacter prevalence in broiler chickens and human illness [27]. In Switzerland, poultry consumption has increased in the past 25 years. While the average per capita consumption was $7.8 \mathrm{~kg}$ in 1988, it was 11.4 $\mathrm{kg}$ in $2013[28,29]$.

Eggs and egg-containing products were shown to be risk factors for salmonellosis in Switzerland in 1993 [30]. The legislating authorities addressed the risk of these food-borne pathogens by setting and enforcing microbiological criteria.

As early as 1969, an official method to detect enteritic Salmonella in foods was published in the Swiss Food Manual [31]. Also, guidance levels for Salmonella in different food categories were given.

In 1981, legal microbiological criteria for foods were decreed for the first time in a Federal Ordinance [32]. Criteria for Salmonella were as follows. For baby foods and diet products: not detectable (nd) in $50 \mathrm{~g}$; drinking water: nd in $5 \mathrm{l}$; other products: nd in $20 \mathrm{~g}$. For 'other products', authorities could refrain from measures if the product in question had to undergo treatment (e.g. cooking) prior to consumption. In 1995, after a revision of the ordinance, criteria for Salmonella were set at as follows. For baby foods: nd in $50 \mathrm{~g}$; drinking water: nd in 5 l; ready-to-eat foods: nd in $25 \mathrm{~g}$; and spices: nd in $25 \mathrm{~g}$ [33]. In 2005, Swiss food legislation adopted 
Trends in Salmonella notification rates between age groups and sexes, Switzerland 1988-2013

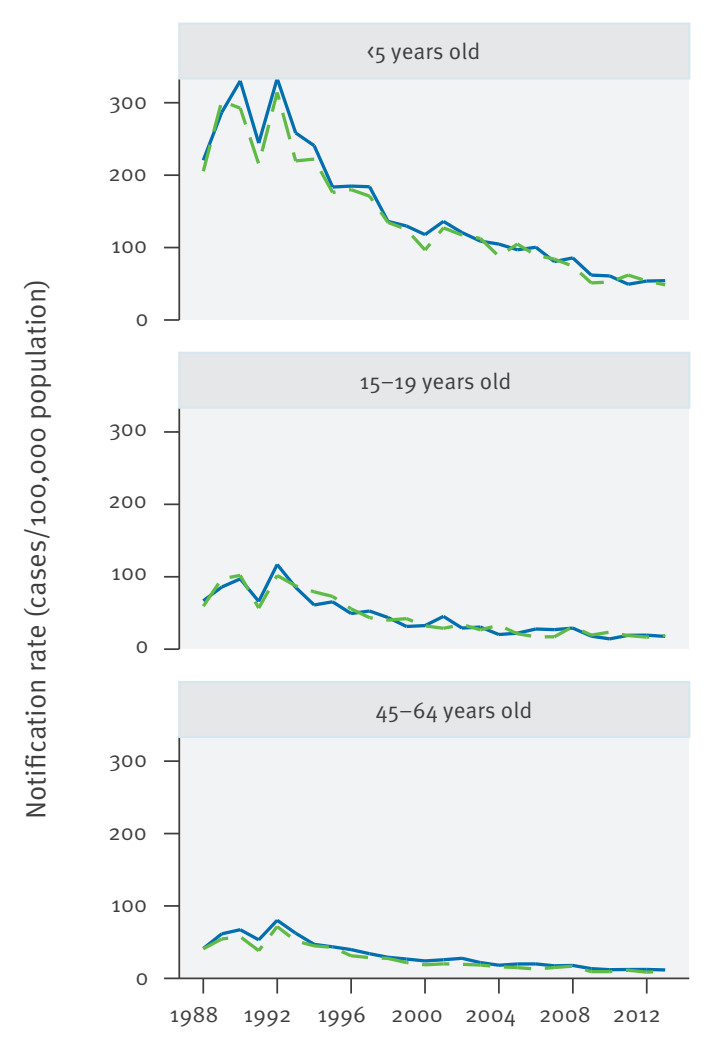

Graphs by age group
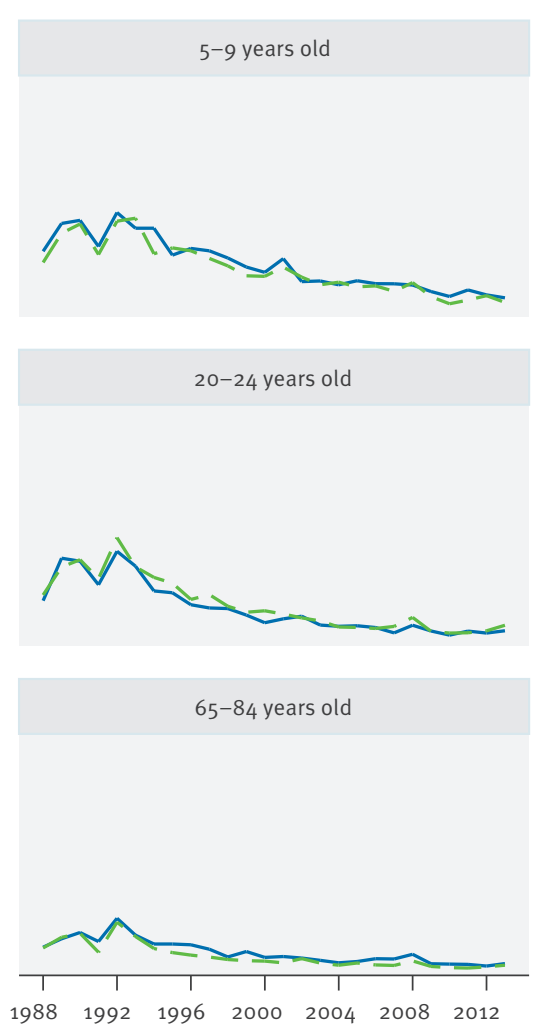

Year
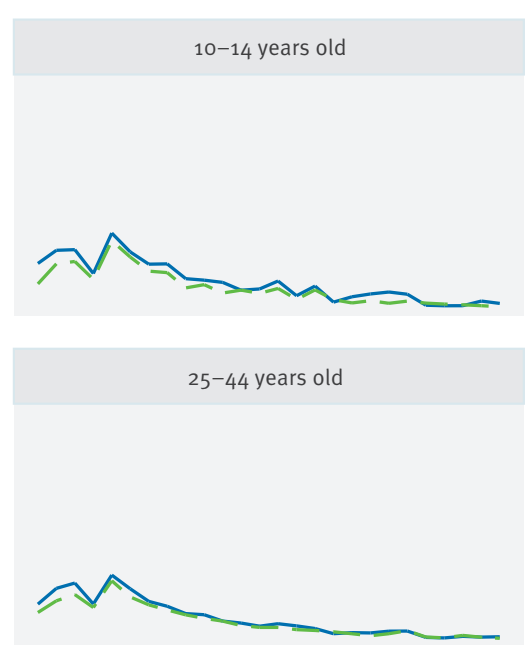

$85+$ years old

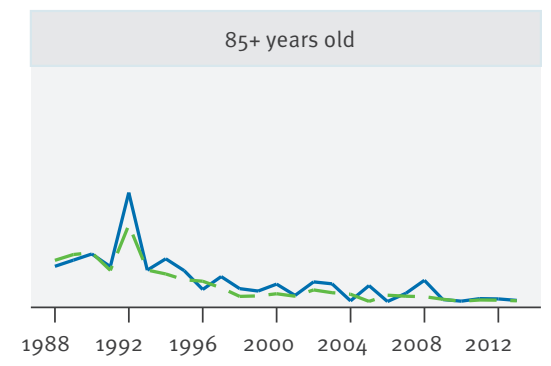

Males $\quad---$ Females

the European Union's microbiological criteria for Salmonella in food [34].

Salmonella limits for some categories of raw meat were issued as the national law adapted to EU hygiene regulations in 2006 [35]. To combat the epidemic with S. Enteritidis in eggs, mandatory screening of layer hens and measures to eradicate positive flocks were decreed by the Ordinance for the Control and Eradication of Epizoonotic Diseases as early as 1993 [36]. Apart from a ban on battery-caged chicken rearing (in effect since 1992 [37]), no further measures (such as vaccinations of layer hens against $S$. Enteritidis) are implemented in Switzerland.

As early as 1987, a limit for Campylobacter was decreed in the Ordinance on Hygiene, which was 'not detectable in $10 \mathrm{~g}$ of ready-to-eat foods' (later, not detectable in $25 \mathrm{~g}$ ) after enrichment. This microbiological criterion was abrogated in 2006. To address the risk of Campylobacter in connection with poultry liver, since 2014 the Ordinance has stipulated that poultry liver must be sold frozen if it cannot be shown that the product comes from a Campylobacter-free flock [35]. Furthermore, a process hygiene criterion to minimise Campylobacter in poultry slaughterhouses is underway and should enter into force in 2016. However, criteria for Campylobacter on raw poultry meat are not currently being considered.

Relevant epidemiological studies in Switzerland In $2013,37.7 \%(169 / 448)$ of broiler flocks and $65 \%$ (226/348) of rectum-anal swab samples taken from pigs at slaughter tested positive for Campylobacter [38]. In the same year, only $1 \%$ of 3,636 samples of fresh poultry meat, poultry meat preparations and poultry meat products at different stages of processing tested positive for Salmonella. Twenty-three years prior, Salmonella contamination levels in Switzerland were much higher. In a 1990 study, $19.2 \%$ of chicken neck skin lobs and $47.7 \%$ of broiler flocks were found to be Salmonella-positive [39]. As a consequence, Salmonella control measures as described above were implemented in the 1990 s and led to a significant reduction in the number of human cases reported.

In Switzerland, salmonellosis and campylobacteriosis case curves crossed in 1995; in Austria, it was in 2006 [40]. The reason for this striking difference might be that Switzerland addressed the epidemic of $S$. Enteritidis in eggs at a very early stage.

The reduction of domestic salmonellosis cases resulted in a higher prominence of travel-associated 
Comparison of notification rates for Campylobacter and Salmonella among different age groups, Switzerland, 1988 and 2013

\begin{tabular}{|c|c|c|c|c|c|c|}
\hline \multirow{3}{*}{$\begin{array}{l}\text { Age } \\
\text { group }\end{array}$} & \multicolumn{3}{|c|}{ Campylobacter } & \multicolumn{3}{|c|}{ Salmonella } \\
\hline & \multicolumn{2}{|c|}{ Notification rate } & \multirow{2}{*}{$\begin{array}{c}\% \\
\text { increase }\end{array}$} & \multicolumn{2}{|c|}{ Notification rate } & \multirow{2}{*}{$\begin{array}{c}\% \\
\text { increase }\end{array}$} \\
\hline & 1988 & 2013 & & 1988 & 2013 & \\
\hline$<5$ & $105 \cdot 3$ & 102.3 & $-3 \%$ & 216.1 & 51.5 & $-76 \%$ \\
\hline $5-9$ & 49.9 & 62.9 & $+26 \%$ & 85.1 & 23.4 & $-73 \%$ \\
\hline $10-14$ & 29.7 & 58.1 & $+96 \%$ & 59.1 & 15.1 & $-74 \%$ \\
\hline $15-19$ & 54.7 & 108.1 & $+98 \%$ & 63.4 & 18.1 & $-71 \%$ \\
\hline $20-24$ & 97.4 & 160.7 & $+65 \%$ & 68.1 & 25.3 & $-63 \%$ \\
\hline $25-44$ & 49.2 & 91.2 & $+85 \%$ & 51.6 & 10.6 & $-79 \%$ \\
\hline $45-64$ & 24.4 & 78.3 & $+221 \%$ & 41.1 & 10.9 & $-73 \%$ \\
\hline $65-84$ & 19.2 & 100.1 & $+421 \%$ & 38.6 & 15.1 & $-61 \%$ \\
\hline $85^{+}$ & 11.7 & 92.2 & $+688 \%$ & 62.7 & 9.3 & $-85 \%$ \\
\hline
\end{tabular}

transmission risks in relative terms, which was shown by Schmid and Baumgartner: the (relative) proportion of travel-associated S. Enteritidis cases increased substantially from $20 \%$ in 1993 to $45 \%$ in 2011/12 [41]. Two case-control studies on campylobacteriosis $[5,26]$ and a case-control study on salmonellosis [30] conducted in Switzerland identified travel abroad as a risk factor for the diseases. However, this finding has to be interpreted with care, as patients with travel history are more likely to be tested (data not shown) and all studies recruited laboratory-confirmed cases.

The observed winter peak in Campylobacter infections can be attributed partly to the traditional consumption of meat fondue over Christmas and New Year [5]. However, it is not known why this winter peak has been more pronounced in the past few years. Given the increasing per capita consumption of poultry meat $[28,29]$, one could hypothesise that poultry has become more popular in meat fondues.

Outbreaks due to Campylobacter or Salmonella also occurred in Switzerland. However, the number of foodborne outbreaks decreased significantly between 1993 and 2010, mainly due to the reduction of salmonellosis [12]. The number of registered Salmonella outbreaks dropped from 27 in 1993 to one in 2010 while the number of Campylobacter outbreaks varied between none and five throughout this time period. In relation to the number of cases, Salmonella is causing more outbreaks than Campylobacter both in Europe and in Switzerland.

\section{Public awareness and knowledge about the diseases}

Public awareness and people's knowledge of Campylobacter and Salmonella in Switzerland are as different as the trends observed in the two pathogens in the NNSID. In 2011, a consumer survey showed that $76 \%$ of participants were 'very concerned' or 'somewhat concerned' about Salmonella in foods [42]. Only
$1 \%$ of respondents stated that they had not heard of the Salmonella bacterium. In contrast, only $33 \%$ were 'very concerned' or 'somewhat concerned' about Campylobacter and more than half ( $52 \%)$ had not heard of the pathogen. Unpublished data from a recent casecontrol study in Switzerland [5] confirm those figures: $55 \%$ of people infected with campylobacteriosis (cases) and $68 \%$ of healthy people (population-based controls) had never heard of Campylobacter, while only $2 \%$ of cases and $3 \%$ of controls had never heard of Salmonella.

The lack of knowledge about safe food handling and avoidance of cross-contamination, and low personal risk perception are the main reasons for unsafe food handling $[23,43]$. The high prevalence of Campylobacter in chicken products, the low infective dose of Campylobacter and the increasing consumption of chicken meat combined with the apparent lack of knowledge about the Campylobacter-pathogen are all factors facilitating infection.

\section{Conclusions}

Campylobacter spp. infections are a serious and increasing public health concern in Switzerland. For Salmonella spp. infections, an epidemiological turnaround has been achieved through concerted efforts and legal regulations of the poultry- and food-production industries, but little has been done to date to prevent Campylobacter infections on a large scale. Food safety interventions before the sale of poultry meat are urgently required to reduce Campylobacter contamination frequencies. Since the number of control options is limited, the hygienic treatment of chicken carcasses with chemicals, for example peracetic acid, should not be excluded from discussion [44]. However, the population's limited awareness of Campylobacter must also be addressed. It seems reasonable to believe that the same type of behaviour changes that reduced Salmonella infections can be applied to prevent Campylobacter infections and that caution can be extended from eggs to raw poultry meat, cutting boards and knives.

\section{Acknowledgements}

We thank all Swiss diagnostic laboratories for their valuable routine work in reporting to the national health information system. We thank the Notification Systems staff at the Federal Office of Public Health for maintaining the NNSID data base and for their continued assistance in accessing the data. The authors gratefully acknowledge the critical review of and inputs to the manuscript of Philipp Bless and Christoph Hatz, the statistical support of Jan Hattendorf and the language editing of Amena Briët, all Swiss Tropical and Public Health Institute. No funding was received for this study. We used public data from the Federal Office of Public Health and from the Federal Statistical Office only.

Conflict of interests

The authors declare that they have no conflict of interest. 


\section{Authors' contributions}

DM and MM conceived the idea of and designed the study with CS; MJ provided the data; CS and DM analysed the data and CS wrote the first draft; MJ, AB, MM and DM contributed to the interpretation of the data, writing and reviewing of the manuscript.

\section{References}

1. Schweizerischer Bundesrat [Swiss Federal Council]. Verordnung über die Meldung übertragbarer Krankheiten des Menschen (Melde-Verordnung) vom 13. Januar 1999 (Stand am 1. Januar 2014); SR 818.141.1. [Ordinance on disease notification of humans from 13 January 1999 (version from 1 January 2014)]. Bern: The Swiss Federal Council; 2014. German. Available from http://www.admin.ch/ch/d/sr/8/818.141.1.de.pdf

2. Schweiger A, Markwalder K, Vogt M. Infektiöse Diarrhoe: Epidemiologie, Klinik und Diagnostik. [Infectious diarrhoea: epidemiology, symptoms and diagnostic.]. Schweiz Med Forum. 2005;5:714-23. German.

3. Man SM. The clinical importance of emerging Campylobacter species.Nat Rev Gastroenterol Hepatol. 2011;8(12):66985. Available from: DOI: 10.1038/nrgastro.2011.191 PMID: 22025030

4. Braam HP. Campylobacter Enteritis. In: Heymann DL, editor. Control of Communicable Diseases Manual. 18th ed. Washington, DC: American Public Health Association; 2004. p. 81-4.

5. Bless PJ, Schmutz C, Suter K, Jost M, Hattendorf J, MäusezahlFeuz $M$, et al. A tradition and an epidemic: determinants of the campylobacteriosis winter peak in Switzerland. Eur J Epidemiol. 2014;29(7):527-37. Available from: DOI: 10.1007/ S10654-014-9917-0 PMID: 24990236

6. Poropatich KO, Walker CL, Black RE. Quantifying the association between Campylobacter infection and GuillainBarré syndrome: a systematic review.J Health Popul Nutr. 2010;28(6):545-52. Available from: DOI: 10.3329/jhpn. v28i6.6602 PMID: 21261199

7. Barton Behravesh C, Jones TF, Vugia DJ, Long C, Marcus R, Smith K, et al. FoodNet Working Group. Deaths associated with bacterial pathogens transmitted commonly through food: foodborne diseases active surveillance network (FoodNet), 1996-2005. J Infect Dis. 2011;204(2):263-7. Available from: DOI: 10.1093/infdis/jir263 PMID: 21673037

8. Christenson JC. Salmonella infections.Pediatr Rev. 2013;34(9):375-83. Available from: DOI: 10.1542/pir.34-9-375 PMID: 24000341

9. Braam P. Salmonellosis. In: Heymann DL, editor. Control of Communicable Diseases Manual. 18th ed. Washington, DC: American Public Health Association; 2004. p. 469-73.

10. Kothary MH, Babu US. Infective dose of foodborne pathogens in volunteers: A review.J Food Saf. 2001;21(1):49-68. Available from: DOI: $10.1111 / j .1745-4565.2001 . t b 00307 . x$

11. Teunis PF, Kasuga F, Fazil A, Ogden ID, Rotariu O, Strachan NJ. Dose-response modeling of Salmonella using outbreak data. Int J Food Microbiol. 2010;144(2):243-9. Available from: DOI: 10.1016/j.ijfoodmicro.2010.09.026 PMID: 21036411

12. Schmid H, Baumgartner A. Foodborne outbreaks in Switzerland - Current statistics, future developments, practical guidelines for the investigation of outbreaks and a historical review. Bern: The Federal Office of Public Health; 2012.

13. European Food Safety Authority (EFSA), European Centre for Disease Prevention and Control (ECDC),. The European Union summary report on trends and sources of zoonoses, zoonotic agents and food-borne outbreaks in 2013.EFSA Journal.2015;13(1):3991.

14. Bundesamt für Statistik (BFS). STAT-TAB: Die interaktive Statistikdatenbank. Neuchâtel: Federal Statistical Office; 2014 [Accessed 26 Nov 2014]. German. Available from: http://www. pxweb.bfs.admin.ch

15. Janiec J, Evans MR, Thomas DR, Davies GH, Lewis $\mathrm{H}$. Laboratory-based surveillance of Campylobacter and Salmonella infection and the importance of denominator data. Epidemiol Infect. 2012;140(11):2045-52. Available from: DOI: 10.1017/S0950268811002822 PMID: 22217369

16. des Innern DED. Verordnung des EDI über die Meldung von Beobachtungen übertragbarer Krankheiten des Menschen vom 1. Dezember 2015 (Stand am 1. Januar 2016); SR 818.101.126. [Ordinance of the FDHA on the notification of observations on human communicable diseases from 1. December 2015 (version from 1 January 2016)]. Bern: Federal Department of Home Affairs; 2016. German. Available from: https://www.admin.ch/ opc/de/classified-compilation/20151622/index.html
17. Schielke A, Rosner BM, Stark K. Epidemiology of campylobacteriosis in Germany - insights from 10 years of surveillance.BMC Infect Dis. 2014;14(1):30. Available from: DOI: $10.1186 / 1471-2334-14-30$ PMID: 24422983

18. Nichols GL, Richardson JF, Sheppard SK, Lane C, Sarran C. Campylobacter epidemiology: a descriptive study reviewing 1 million cases in England and Wales between 1989 and 2011. BMJ Open. 2012;2(4):eo01179. Available from: DOI: 10.1136/ bmjopen-2012-001179 PMID: 22798256

19. Mughini Gras L, Smid JH, Wagenaar JA, Koene MG, Havelaar $\mathrm{AH}$, Friesema IH, et al. Increased risk for Campylobacter jejuni and $C$. coli infection of pet origin in dog owners and evidence for genetic association between strains causing infection in humans and their pets. Epidemiol Infect. 2013;141(12):2526. 35. Available from: DOI: 10.1017/So950268813000356 PMID: 23445833

20. Gillespie IA, O’Brien SJ, Penman C, Tompkins D, Cowden J, Humphrey TJ. Demographic determinants for Campylobacter infection in England and Wales: implications for future epidemiological studies.Epidemiol Infect. 2008;136(12):171725. Available from: DOI: 10.1017/So950268808000319 PMID: 19000328

21. Bavishi C, Dupont HL. Systematic review: the use of proton pump inhibitors and increased susceptibility to enteric infection. Aliment Pharmacol Ther. 2011;34(11-12):1269-81. Available from: DOI: 10.1111/j.1365-2036.2011.04874.x PMID: 21999643

22. Brophy S, Jones KH, Rahman MA, Zhou SM, John A, Atkinson $\mathrm{MD}$, et al. Incidence of Campylobacter and Salmonella infections following first prescription for PPI: a cohort study using routine data. Am J Gastroenterol. 2013;108(7):1094-100. Available from: DOI: 10.1038/ajg.2013.30 PMID: 23588238

23. Bearth A, Cousin ME, Siegrist M. Poultry consumers' behaviour, risk perception and knowledge related to campylobacteriosis and domestic food safety.Food Contr. 2014;44:166-76. Available from: DOI: 10.1016/j. foodcont.2014.03.055

24. Kittl S, Heckel G, Korczak BM, Kuhnert P. Source attribution of human Campylobacter isolates by MLST and fla-typing and association of genotypes with quinolone resistance.PLoS One. 2013;8(11):e81796. Available from: DOI: 10.1371/journal. pone.0081796 PMID: 24244747

25. Kittl S, Kuhnert P, Hächler H, Korczak BM. Comparison of genotypes and antibiotic resistance of Campylobacter jejuni isolated from humans and slaughtered chickens in Switzerland.J Appl Microbiol. 2011;110(2):513-20. Available from: DOI: 10.1111/j.1365-2672.2010.04906.x PMID: 21143711

26. Schorr D, Schmid H, Rieder HL, Baumgartner A, Vorkauf $\mathrm{H}$, Burnens A. Risk factors for Campylobacter enteritis in Switzerland.Zentralbl Hyg Umweltmed. 1994;196(4):327-37. PMID: 7748438

27. Wei W, Schüpbach G, Held L. Time-series analysis of Campylobacter incidence in Switzerland.Epidemiol Infect. 2015;143(9):1982-9. Available from: DOI: 10.1017/ So950268814002738 PMID: 25400006

28. Proviande - Die Branchenorganisation der Schweizer Fleischwirtschaft. Der Fleischmarkt im Überblick: Jährlicher Konsum 2013. [The meat market at a glance: Annual consumption 2013.] Bern: Proviande; 2014 [Accessed 19 Jan 2015]. German. Available from http://www.schweizerfleisch. $\mathrm{ch} /$ dienstleistungen/statistik/publikationen/fleischkonsum/

29. Proviande WB. Infografik: Fleischkonsum in der Schweiz stagniert. [Info graphic: Meat consumption in Switzerland stagnates.] Bern: Landwirtschaftlicher Informationsdienst (LID); 2010 [Accessed 19 Jan 2015]. German. Available from: http://www.lid.ch/de/medien/mediendienst/archyear/2086/

30. Schmid H, Burnens AP, Baumgartner A, Oberreich J. Risk factors for sporadic salmonellosis in Switzerland.Eur J Clin Microbiol Infect Dis. 1996;15(9):725-32. Available from: DOI: 10.1007/BF01691959 PMID: 8922572

31. Lebensmittelbuch S. (SLMB) [Swiss Food Manual]. Kapitel 56 "Mikrobiologie und Hygiene" [chapter 56 "Microbiology and Hygiene"]. Bern: Federal Office of Public Health, 1969

32. Das Eidgenössische Departement des Innern [Federal Department of Home Affairs]. Verordnung über die hygienischmikrobiologischen Anforderungen an Lebensmittel, Gebrauchsund Verbrauchsgegenstände vom 14. September 1981; SR 817.024 . [Ordinance on the hygienic and microbiological requirements for foodstuff, utility- and consumable articles from 14 September 1981]. Bern: Federal Department of Home Affairs; 1981. German.

33. Das Eidgenössische Departement des Innern [Federal Department of Home Affairs]. Verordnung über die hygienischmikrobiologischen Anforderungen an Lebensmittel, Gebrauchsgegenstände, Räume, Einrichtungen und Personal vom 26. Juni 1995 (Stand am 1. Januar 1996); SR 817.051. [Ordinance on the hygienic and microbiological requirements 
for foodstuff, utilities, rooms, facilities and personnel from 26 June 1995 (version from 1 January 1996)]. Bern: Federal Department of Home Affairs; 1996. German.

34. Das Eidgenössische Departement des Innern [Federal Department of Home Affairs]. Hygieneverordnung des EDI (HyV) vom 23. November 2005 (Stand am 12. Dezember 2006); SR 817.024.1. [Ordinance on food hygiene from 23 November 2005 (version from 12 December 2006)]. Bern: Federal Department of Home Affairs; 2006. German. Available from http://www.admin.ch/opc/de/classified-compilati on $/ 20050160 / 200701010000 / 817.024 .1$

35. Das Eidgenössische Departement des Innern [Federal Department of Home Affairs]. Hygieneverordnung des EDI (HyV) vom 23. November 2005 (Stand am 1. Januar 2014); SR 817.024 .1 . [Ordinance on food hygiene from 23 November 2005 (version from 1 January 2014)]. Bern: Federal Department of Home Affairs; 2014. German. Available from: http://www. admin.ch/ch/d/sr/8/817.024.1.de.pdf

36. Schmid H, Baumgartner A. Salmonella enterica serovar Enteritidis in Switzerland: recognition, development, and control of the epidemic. In: Saeed AM, Gast RK, Potter ME, Wall PG, editors. Salmonella enterica serovar Enteritidis in humans and animals - Epidemiology, pathogenesis, and control. Ames: lowa State University Press; 1999.

37. Kaufmann-Bart M, Hoop RK. Diseases in chicks and laying hens during the first 12 years after battery cages were banned in Switzerland.Vet Rec. 2009;164(7):203-7. Available from: DOI: 10.1136/vr.164.7.203 PMID: 19218590

38. Bundesamt für Lebensmittelsicherheit und Veterinärwesen BLV [Federal Food Safety and Veterinary Office, FSVO]. Switzerland - Trends and sources of zoonoses and zoonotic agents in humans, foodstuffs, animals and feedingstuffs - in 2013. Report to the European Commission. Bern: FSVO; 2014. Available from: http://www.blv.admin.ch/ dokumentation/00327/04538/04815/index.html?lang=de

39. Baumgartner A, Heimann P, Schmid H, Liniger M, Simmen A. Salmonella contamination of poultry carcasses and human salmonellosis. Arch Lebensm Hyg.1992;43:123-4.

40. Much P, Rendi-Wagner P, Herzog U. Bericht über Zoonosen und ihre Erreger in Österreich im Jahr 2013. [Report on zoonoses and zoonotic pathogens in Austria in 2013.] Vienna: Bundesministerium für Gesundheit, AGES - Österreichische Agentur für Gesundheit und Ernährungssicherheit $\mathrm{GmbH}$; 2014. German. Available from: http://www.ages.at/fileadmin/ AGES2015/Themen/Krankheitserreger_Dateien/Zoonosen/ Zoonosenbericht_2013.pdf

41. Schmid H, Baumgartner A. Epidemiology of infections with enteric salmonellae in Switzerland with particular consideration of travelling activities.Swiss Med Wkly. 2013;143:W13842.PMID: 23986302

42. Coop, Schweizerische Gesellschaft für Ernährung. Ess-Trends im Fokus 6 - "Essen? Aber sicher!" [Dining trends in focus 5: 'Hungry? Eat, but safely!'] Basel: Coop; 2011. German. Available from: http://www.coop.ch/pb/site/common2/ node/79912766/Lde/index.html

43. Bearth A, Cousin ME, Siegrist M. Uninvited guests at the table - a consumer intervention for safe poultry preparation.J Food Saf. 2013;33(4):394-404. Available from: DOI: 10.1111/jfs.12063

44. Nagel GM, Bauermeister LJ, Bratcher CL, Singh M, McKee SR. Salmonella and Campylobacter reduction and quality characteristics of poultry carcasses treated with various antimicrobials in a post-chill immersion tank.Int J Food Microbiol. 2013;165(3):281-6. Available from: DOI: 10.1016/j. ijfoodmicro.2013.05.016 PMID: 23800739

\section{License and copyright}

This is an open-access article distributed under the terms of the Creative Commons Attribution (CC BY 4.0) Licence. You may share and adapt the material, but must give appropriate credit to the source, provide a link to the licence, and indicate if changes were made.

This article is copyright of the authors, 2016. 